\title{
18. MESOZOIC FORAMINIFERS AND MICROFACIES FROM HOLES 400A, 401 AND 402A OF THE DSDP LEG 48
}

\author{
P. A. Dupeuble, Laboratoire de Géologie, Faculté des Sciences, Université de Rouen, 76130 Mont-Saint-Aignan, France
}

\section{FOREWORD}

The main object of this paper is to present the principal foraminifer assemblages that establish the chronostratigraphy of the Mesozoic deposits encountered during drilling on Leg 48, and to interpret the paleoenvironmental conditions that existed during sedimentation. No systematic discussion will be presented here. Detailed study of benthic foraminiferal assemblages has not been undertaken; only the dominant characteristics of these assemblages will be given where they have environmental significance.

\section{INTRODUCTION}

During Leg 48 of the IPOD phase of the Deep Sea Drilling Project, Mesozoic deposits were penetrated at three sites in the Bay of Biscay (Figure 1). The oldest layers reached are of Aptian age in Holes 400A and 402A and of Upper Jurassic age at Site 401. The Mesozoic sequence is zoned according to the scheme of Sigal (1976), which is shown in Table 1.

The first part of the paper presents the chronostratigraphic data from the bottom to the top of the section in each site; the second part involves discussion of the paleontological assemblages in attempt to establish a paleoenvironmental reconstruction.

\section{CHRONOSTRATIGRAPHY}

\section{Hole 400A}

From Core 74 to Core 72 planktonic foraminifers are rare whereas siliceous organisms, especially radiolarians, constitute the main part of the coarse fraction; in Sample 74, $\mathrm{CC}$, the largest ones are pyritized. Benthic foraminifers are rare and represented only by "primitive agglutinates" and some Gyroidinoides and Lenticulinids which show some dissolution. The presence of three specimens of Globigerinelloides ferreolensis Moullade in Sample 72, CC allows us to assign an upper Aptian (Gargasian) age ( $G$. ferreolensis Zone $=\mathrm{MCi} 20$ ) to those cores. The Schackoina cabri Zone, which indicates the Gargasian/Bedoulian boundary, does not appear to have been reached.

Globigerinelloides algerianus Cushman and Ten Dam, guide-species of the following zone ( $\mathrm{MCi} 21)$, is present in rare specimens, together with Hedbergella trocoidea (Gandolfi), in Core 71 (especially in Sample 71, CC).

The Hedbergella trocoidea Zone (MCi 22) of the late Aptian is determined from Sample 70, CC to Sample 68-2, $111-113 \mathrm{~cm} ; H$. trocoidea (Gandolfi) is often abundant and

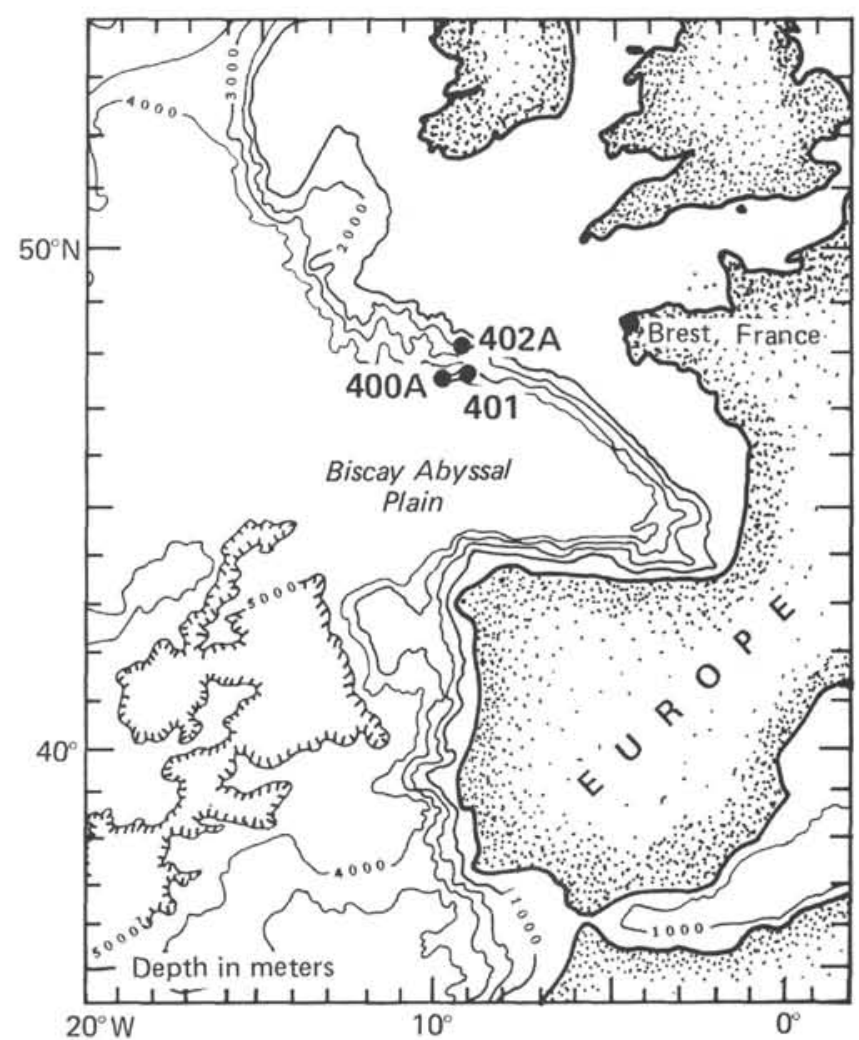

Figure 1. Location map of Hole 400A, Site 401, and Hole $402 A$.

of relatively large size in the main part of this sequence (Caron et al., 1969).

The first occurrence of Ticinella bejaouaensis Sigal in Sample 68-1, 95-97 cm indicates the beginning of Zone MCi 23. This zone begins in the uppermost Aptian and ends in the lower part of the lower Albian. T. bejaouaensis Sigal continues to be present to Sample 66-2, 63-67 cm. Because of poor recovery in Core 67, the Aptian/Albian boundary is difficult to locate precisely, but the presence of Pleurostomella subnodosa Reuss in Sample 66-4, 75-79 cm and its absence in Core 68, Section 1 argue for putting the boundary between Core 68, Section 1 and Sample 66, CC (Moullade, 1974).

From Core 66 to Core 63 detailed chronostratigraphy is not easily established because planktonic foraminifers are often rare or poorly preserved and always small, whereas radiolarians are abundant in the coarser fraction. This is mainly due to the presence of carbonaceous mudstone intercalations within this sequence (see paleoenvironmental 
TABLE 1

Tentative Zonation for the Cretaceous in the Mediterranean Areas Based on Planktonic Foraminifers

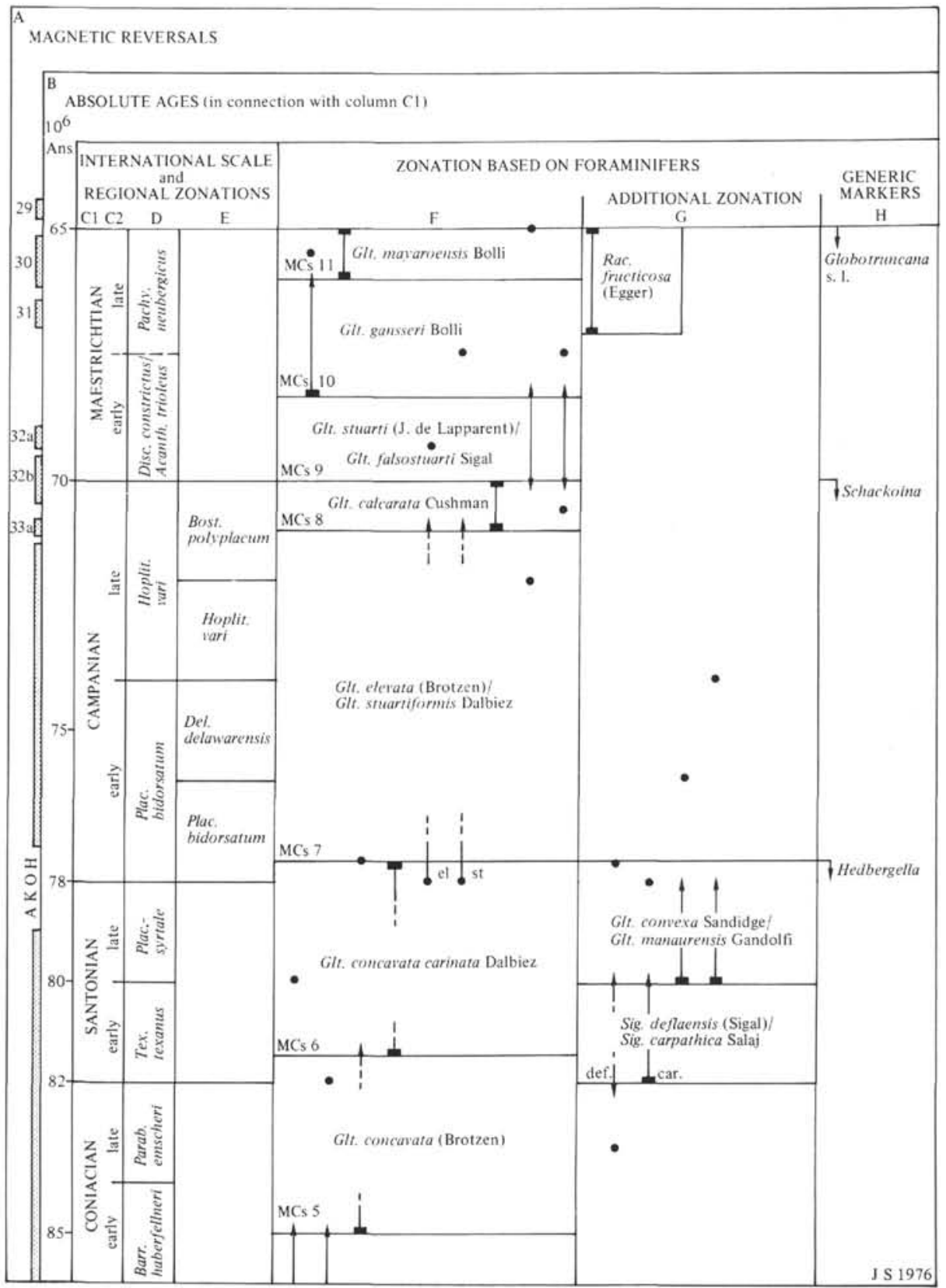

observations and also Auffret et al., this volume). The few small planktonic foraminifers that are present are mainly Hedbergella planispira (Tappan) and it is probable that Section 66-1 to Section 64-1 encompasses the H. planispira Zone ( $\mathrm{MCi} 24)$ with, possibly, the Hedbergella rischi/Ticinella primula Zone ( $\mathrm{MCi} 25)$ at the top of this sequence. Benthic foraminifer assemblages are mainly characterized by Gavelinellidae, Gyroidinoides gr. primitiva (Hofker), Osangularia utaturensis (Sastry and Sastri), Pleurostomella subnodosa Reuss, and some Ataxophragmiidae such as Tritaxia pyramidata Reuss and Pseudoclavulina gaultina (Morozova). Thus, the sequence probably includes the upper part of the lower Albian and the middle Albian.
The Ticinella breggiensis Zone (MCi 26), of late Albian age, is present in the interval from Sample $63-4,28-32 \mathrm{~cm}$ to Sample $62-2,28-30 \mathrm{~cm}$, and contains Rotalipora subticinensis (Gandolfi) (especially in Core 63), Rotalipora ticinensis (Gandolfi), Ticinella breggiensis (Gandolfi), Ticinella raynaudi Sigal and Ticinella raynaudi digitalis Sigal. These forms are dominant (often more than $80 \%$ ) except in the darker layers where they may be rare where radiolarians become abundant. Dissolution appears to have been the important controlling factor, sparing only the siliceous organisms and some resistant benthic foraminifers.

At the top of Core 62 the Rotalipora apenninical Planomalina buxtorfi Zone ( $\mathrm{MCi} 27$ ) is reached. Sample $61-1,70-73 \mathrm{~cm}$ contains numerous Planomalina buxtorfi 
TABLE 1 - Continued

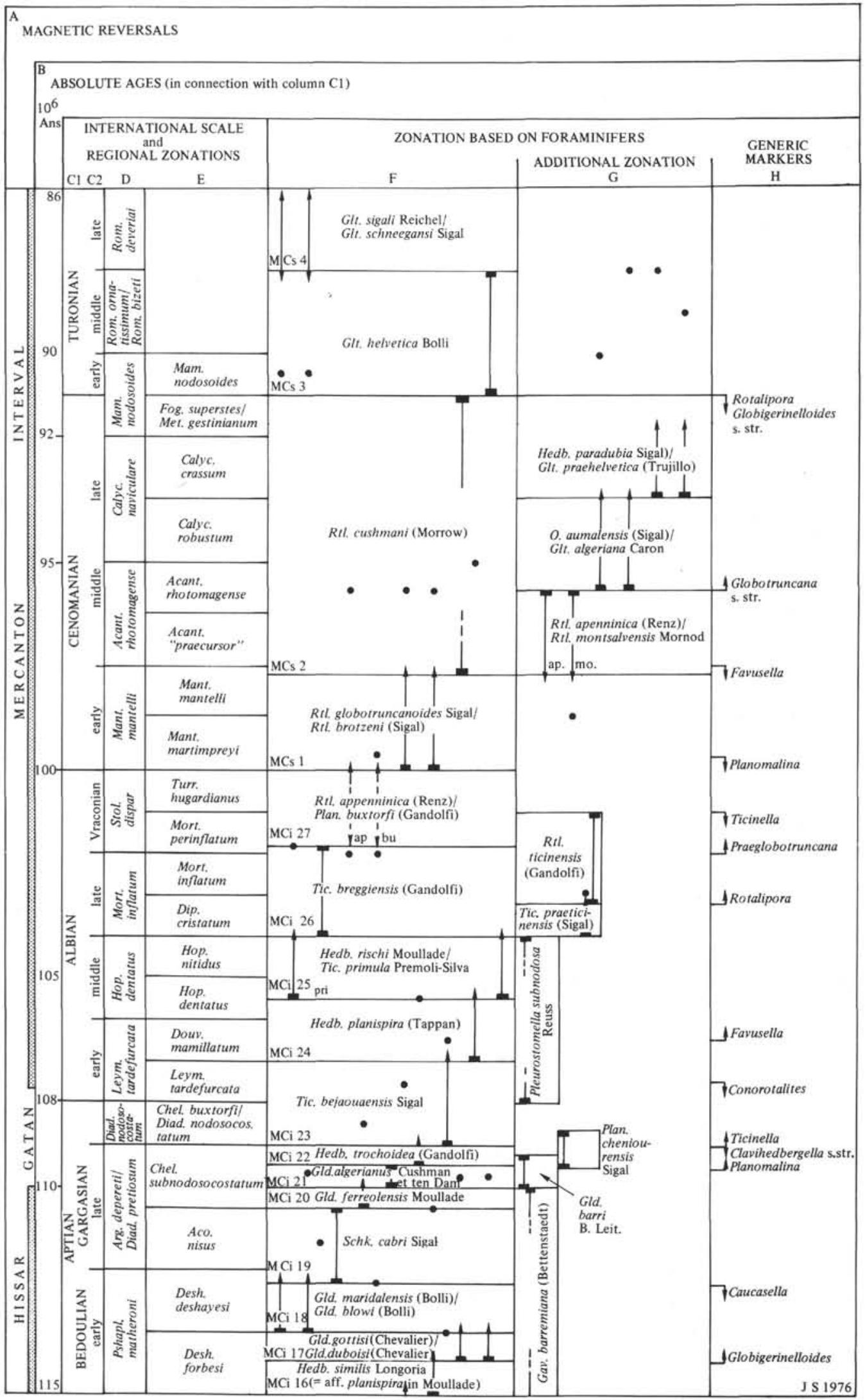


TABLE 1 - Continued

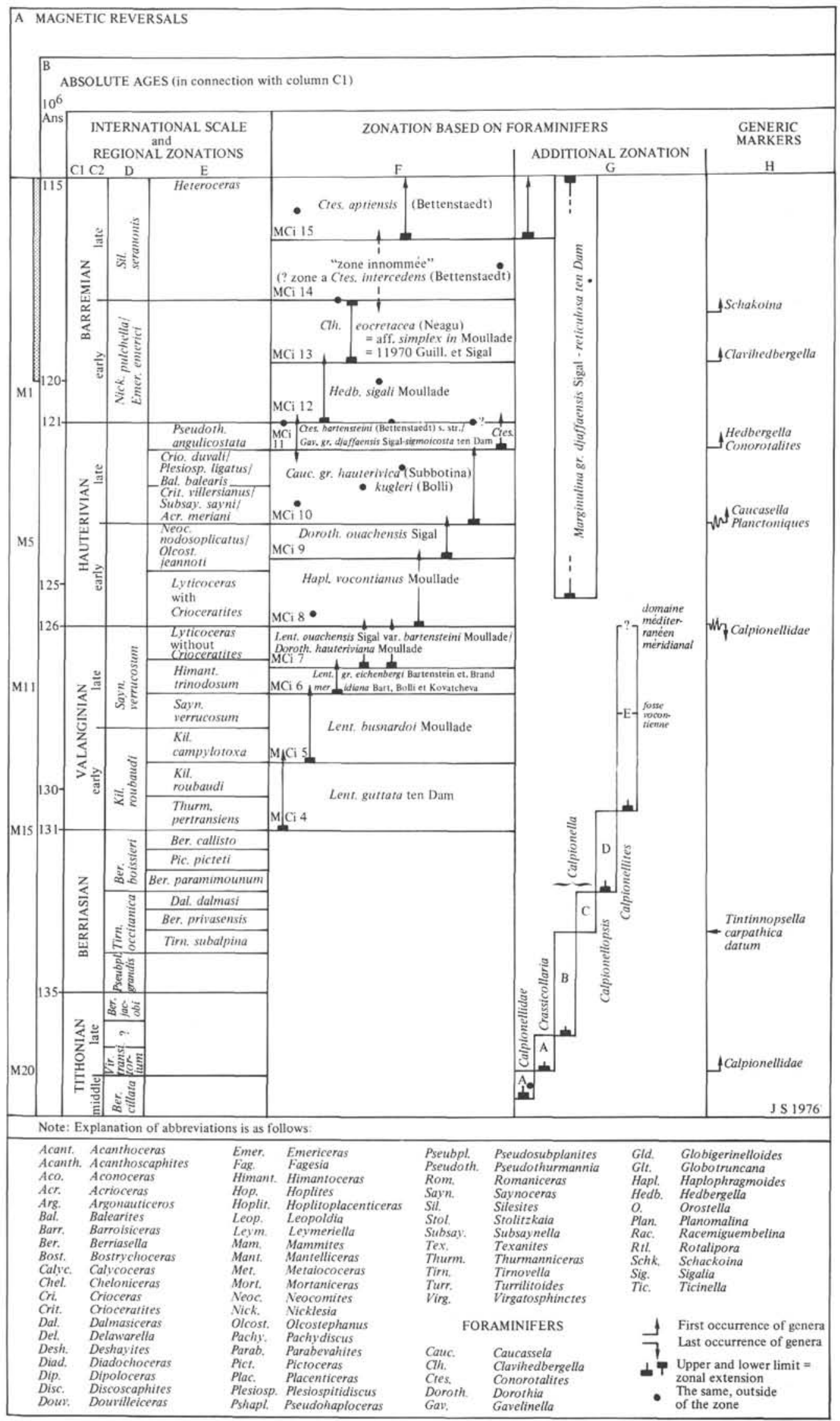


(Gandolfi), Rotalipora ticinensis (Gandolfi), and some Rotalipora balernaensis Gandolfi. Benthic foraminifers such as Pseudoclavulina gaultina (Morozova), $P$. gaultina var. carinata Neagu, Pleurostomella sp., and Osangularia utaturensis (Sastry and Sastri) account for less than 2 per cent; a few radiolarians also are present.

The uppermost cores of the Mesozoic section are Cores 61 and 60 . Unfortunately the sediment does not contain planktonic foraminifers and precise zonation in those cores is difficult. Benthic forms such as Aragonia ouezzanensis (Rey), Osangularia lens Brotzen, Reussella szajnochae (Grzybowski), Praebulimina reussi (Morrow), and Globorotalites michelianus (d'Orbigny) suggest a Campanian to Maestrichtian age. Thus, a hiatus of about 25 million years lies between Lower and Upper Cretaceous. The absence of planktonic foraminifers and the presence of only resistant benthic foraminifers suggest rather strong dissolution.

\section{Site 401}

The Mesozoic sequence (Core 24 to Core 19) at Site 401 consists mostly of indurated sediments, necessitating examination by thin sections.

Cores 23 and 24 comprise a pelletoid and bioclastic limestone, more or less porous (less in the bottom of Core 23), containing echinoid, pelecypod, and coral remains. The foraminifers Conicospirillina basiliensis Mohler, Nautiloculina oolithica Mohler, Trocholina sp., Pseudocyclammina sp. (only fragments), and Kurnubia (?) are present as well as the algae Thaumatoporella parvovesiculifera (Raineri), Lithocodium aggregatum Elliot, Baccinella irregularis Radoicic, and some oncolites; fragments of Cladocoropsis mirabilis Felix also are present. This assemblage is typically Kimmeridgian to Portlandian in age (Ramalho, 1971; Fourcade, 1970).

Recovery was poor in the three next cores consisting of fragments of white, often porous limestone. Sample 22-1, $20-21 \mathrm{~cm}$ is pelletoid and bioclastic and contains Nautiloculina, Trocholina, and Conicospirillina which suggest an Upper Jurassic age. Sample $22-1,10 \mathrm{~cm}$ is particularly rich in large coral fragments. Samples 21-1, 11 $\mathrm{cm}$ and $20-1,1 \mathrm{~cm}$ contain rare sections of calpionelids (Calpionella gr. alpina Lorenz and Tintinopsella gr. carpathica (Murgeanu and Filipescu) which indicate uppermost Tithonian to Berriasian age (Luterbacher, 1972).

The interval from Sample 19-1, $128 \mathrm{~cm}$ to Sample 19-2, $15 \mathrm{~cm}(\mathrm{CC})$ is a hard, reddish bioclastic limestone, at the base of which Baccinella irregularis Radoicic is common. Between $138 \mathrm{~cm}$ and $144 \mathrm{~cm}$ numerous fragments of corals, algae, echinoids, gastropods and, in places, sponge spicules are present with rare Neotrocholina similar to those in the Valanginian of Portugal (Ramalho, 1971). At the top, gastropods, echinoids, and lenticulinids are frequent. The microfacies as a whole is similar to Neocomian beds in southwest France and Portugal, but the absence of good stratigraphical markers does not permit precise age assignment.

Upwards the sediments are not indurated. Samples 19-1, $123-125 \mathrm{~cm}$ and $19-1,127-128 \mathrm{~cm}$ (the latter immediately above the contact with the reddish limestone) contain small, sometimes broken but undissolved planktonic foraminifers, among them Schackoina cabri Sigal, Globigerinelloides duboisi (Chevalier), and Globigerinelloides gottisi (Chevalier) indicating the Schackoina cabri Zone (MCi 19) of early Gargasian time. Sample 19-1, 127-128 cm contains Campanian contaminant planktonic foraminifers probably accumulated there when the drill entered the hard layer below; in Sample 19-1, 123-125 cm, contaminants are rare. From Sample 19-1, 89-92 cm to Sample 19-1, 34-36 cm the sediments encompass the Globotruncana elevatal Globotruncana stuartiformis Zone (MCs 7), of Campanian age, and contain common to abundant specimens of Globotruncana arca (Cushman), G. fornicata Plummer, G. elevata (Brotzen), and G. stuartiformis Dalbiez.

Uppermost Campanian sediments of the Globotruncana calcarata Zone (MCs 8) were recovered from Sample 18-2, $58-60 \mathrm{~cm}$ to Sample 18, CC, wherein Globotruncana calcarata Cushman is relatively common with numerous $G$. fornicata Plummer and G. elevata (Brotzen).

The disappearance of $G$. calcarata Cushman in Sample $18-2,8-10 \mathrm{~cm}$ points to the Campanian/Maestrichtian boundary between this sample and the previous one, and comprises G. stuarti/G. falsostuarti Zone (MCs 9). This zone appears to extend to Sample 18-1, 124-128 cm. The first occurrence of Racemiguembelina fructicosa (Egger) and Globotruncana contusa (Cushman) in Sample 18-1, $86-88 \mathrm{~cm}$ indicates the $G$. gansseri Zone (MCs 10 ) wherein planktonic foraminifers are still abundant, especially $G$. stuarti (de Lapparent), G. contusa (Cushman), and diversified Heterohelicidae.

The boundary with the uppermost Maestrichtian zone (MCs 11) lies between Samples 18-1, 18-20 cm and 18-1, $12-13 \mathrm{~cm}$ where Globotruncana mayaroensis Bolli first occurs. The planktonic assemblage is rich in Globotruncana stuarti (de Lapparent), G. contusa (Cushman), G. conica (White), G. arca (Cushman), G. mayaroensis Bolli, Rugoglobigerina rotundata Bronnimann, $R$. scotti (Bronnimann), Racemiguembelina fructicosa (Egger), Pseudotextularia elegans (Rzehak), Gublerina cuvillieri Kikoine, Planoglobulina sp., and Heterohelix spp.

In general, Upper Cretaceous benthic foraminifers are rare (less than 1\%) in the sequence. Planktonic forms often show signs of dissolution, mainly on the largest specimens.

A hiatus of about 35 million years lies between the uppermost Early Cretaceous deposits and those of the Late Cretaceous.

\section{Hole 402A}

Hole $402 \mathrm{~A}$ ended in the upper part of early Aptian sediments. From Sample 35, CC to Sample 34-1, 18-21 cm, planktonic foraminifers such as Hedbergella cf. infracretacea (Glaessner), Globigerinelloides gottisi (Chevalier), and G. duboisi (Chevalier) indicate the upper Bedoulian $\mathrm{MCi} 17$ to $\mathrm{MCi} 18$ zones. The forms are relatively few and small. Among the benthic species, Lenticulina ouachensis (Sigal) and Globorotalites aptiensis Bettenstaedt corroborate the age assignment (Moullade, 1966, 1974; Chevalier, 1960, 1961; Flandrin et al., 1962; Risch, 1969). 
The first occurrence of Schackoina cabri Sigal and S. pustulans Bolli in Sample 33-5, 33-38 cm indicates the base of the S. cabri Zone (MCi 19) which corresponds to the early Aptian/late Aptian boundary (Longoria, 1974); Globigerinelloides gottisi (Chevalier) and $C$. duboisi (Chevalier) are still present in the fauna. The zone extends to Sample 33-3, 109-113 cm where Schackoinids disappear. In this interval "primitive agglutinates" are common (see W. D. Bock, this volume) mixed with the calcareous benthic foraminifers Gavellinella barremiana Bettenstaedt, G. cf. brotzeni (Gandolfi), Gyroidinoides gr. primitiva (Hofker), and Epistomina caracolla (Roemer); Lenticulinids and Nodosariids are also present.

In Samples 33-1, 111-114 cm, and 33-2, 55-57 cm, the presence of rare Planomalina cheniourensis (Sigal) indicates the Globigerinelloides algerianus Zone (MCi 21) (Gonzales-Donoso et al., 1974); the $G$. ferreolensis Zone (MCi 20) was not identified.

The Hedbergella trocoidea Zone (MCi 22) of late Aptian time was determined in the interval from Sample 32, CC to Sample 31-5, 96-101 cm; it contains H. trocoidea (Gandolfi) specimens which are often of small size. "Primitive agglutinates" and pelecypods remains are common.

The appearance of Ticinella bejaouaensis Sigal in Sample $31-4,59-63 \mathrm{~cm}$ indicates the MCi 23 Zone of uppermost Aptian to lowermost Albian age. The zone extends to Sample 26-1, 72-74 cm wherein $T$. bejaouaensis Sigal is still present; it disappears above. Within the interval, Hedbergella trocoidea (Gandolfi) is common but the number of "primitive agglutinates" decreases from the lower part upward to become very rare in Core 26. Calcareous benthic foraminifers, mainly Epistominidae, Gavelinellinidae, Gyroidinoides, and Lenticulinids, are present.

From Core 25 to Core 11, the detrital sediments therein contain microfossils which often are incrusted. In Sample 24-1, 130-133 cm, gastropods and pelecypods are common whereas planktonic foraminifers are absent; among the benthic ones, such as Gyroidinoides, Osangularia cf. utaturensis (Sastry and Sastri), Lenticulina cephalotes (Reuss), is the first occurrence of Pleurostomella subnodosa Reuss. Thus, the Aptian/Albian boundary lies between the upper part of the Ticinella bejaouaensis Zone and Core 24 . Based on palynomorphs (R. J. Davey, this volume), this boundary is in Core 26, Section 1.

From Core 23 to Core 18 planktonic foraminifers are absent and benthics are incrusted; Epistominidae are conspicuous. Gastropods and pelecypods fragments are often abundant; echinoid spines are common.

Cores 17 to 14 contain some benthic foraminifers $(P$. subnodosa), as well as rare and small planktonics, mainly Hedbergella planispira (Tappan).

Finally, Cores 13 to 11 continue to be barren of planktonic foraminifers. However, Sample 13-2, 14-17 cm contains some well-preserved Epistomina cretosa Ten Dam and Sample 11-3, 107-109 cm contains Pleurostomella subnodosa Reuss and Epistomina spinulifera (Reuss) which point to a middle Albian age. Thus, the interval from Core 25 to Core 11 extends from early to middle Albian and is characterized by planktonic foraminifers being rare to absent; by gastropods and pelecypods being common to abundant; and by Epistominidae being always present and often conspicuous.

The balance of the Mesozoic sequence (Core 10 to Core 5) consists of hard layers in which three main kinds of microfacies were studied by more than 70 thin sections.

The most frequent microfacies is limestones containing abundant sponge spicules and rarely, small remains of algae (Lithothamniae). At some levels the cement is partly silicified and the sediment is very hard. Some samples of this facies show rare sections of small Barkerinidae (i.e., Samples 5-2, $16 \mathrm{~cm} ; 7-1,8 \mathrm{~cm} ; 8-1,26 \mathrm{~cm} ; 9-1,8 \mathrm{~cm} ; 9-1$, $83 \mathrm{~cm}$; and 10-1, $92 \mathrm{~cm}$ ). Sections of Hedbergella cf. washitensis (Carsey) occur in Sample 7-1, $8 \mathrm{~cm}$. This microfacies is similar to the Albian of the northern border of Flysch Formation in southwestern France (Bouroullec et al., 1976; Cuvillier, 1961; Poignant, 1965).

The second kind of microfacies is a bioclastic limestone with frequent echinoid remains and more or less fragments of algae, mainly Agardhiellopsis cretacea Lemoine and Lithophyllum amphiroeformis Rothpletz. The facies is more common in the upper part of the section (i.e., Samples 5-1, $34 \mathrm{~cm} ; 5-1,45 \mathrm{~cm} ; 5-1,63 \mathrm{~cm}$ ) but it is also present in Sample $8-1,3 \mathrm{~cm}$ which contains Hensonia lenticularis (Henson). In Sample 5-1, $12 \mathrm{~cm}$ where algae are rare but echinoids abundant, some sections of Hedbergella washitensis (Carsey) are present. This facies is known from the Albian (especially the upper Albian) of Aquitania (Bouroullec et al., 1976).

The third microfacies is restricted to $30 \mathrm{~cm}$ of white, hard limestone in Core 6-1 from 15 to $45 \mathrm{~cm}$. Thin sections show abundant Pithonella ovalis (Kaufmann) and some Calcisphaerula innominata Bonet. It is also a typical facies from Aquitania ("Alturian" facies) known from the Albian to Late Cretaceous.

On the basis of the microfacies and identifiable fauna, an Albian age (probably upper Albian) is assigned to the whole indurate sequence which ends the Mesozoic section of Hole 402A. Upper Cretaceous layers are absent here, and a hiatus of about 50 million years lies between Mesozoic and Cenozoic deposits. Figure 2 summarizes the chronostratigraphy in the three sites.

\section{PALEOENVIRONMENTAL OBSERVATIONS}

\section{The Upper Jurassic-Lowermost Cretaceous, Site 401}

The indurated layers penetrated at Site 401 (Cores 24 to 19) were deposited in shallow water; the abundant algae, corals, pelecypods, and gastropods suggest a reefal to peri-reefal environment. The presence of calpionelids indicates open sea but the fine-grained matrix of the sediment suggests a low energy level (? in the lee of a reef barrier) and the thickness of their lorica, which is much greater than usual, indicates a high carbonate concentration. It is therefore postulated that the specimens were carried out of their typical environment into the area of deposition. Similar examples were found on "Le Danois" bank in south Biscay (Dupeuble et al., 1977).

\section{Aptian-Albian "Black Shales" Deposits, Holes 400A and $402 \mathrm{~A}$}

On the basis of the Aptian/Albian foraminifer/benthic assemblages in Holes $400 \mathrm{~A}$ and $402 \mathrm{~A}$, the environmental 


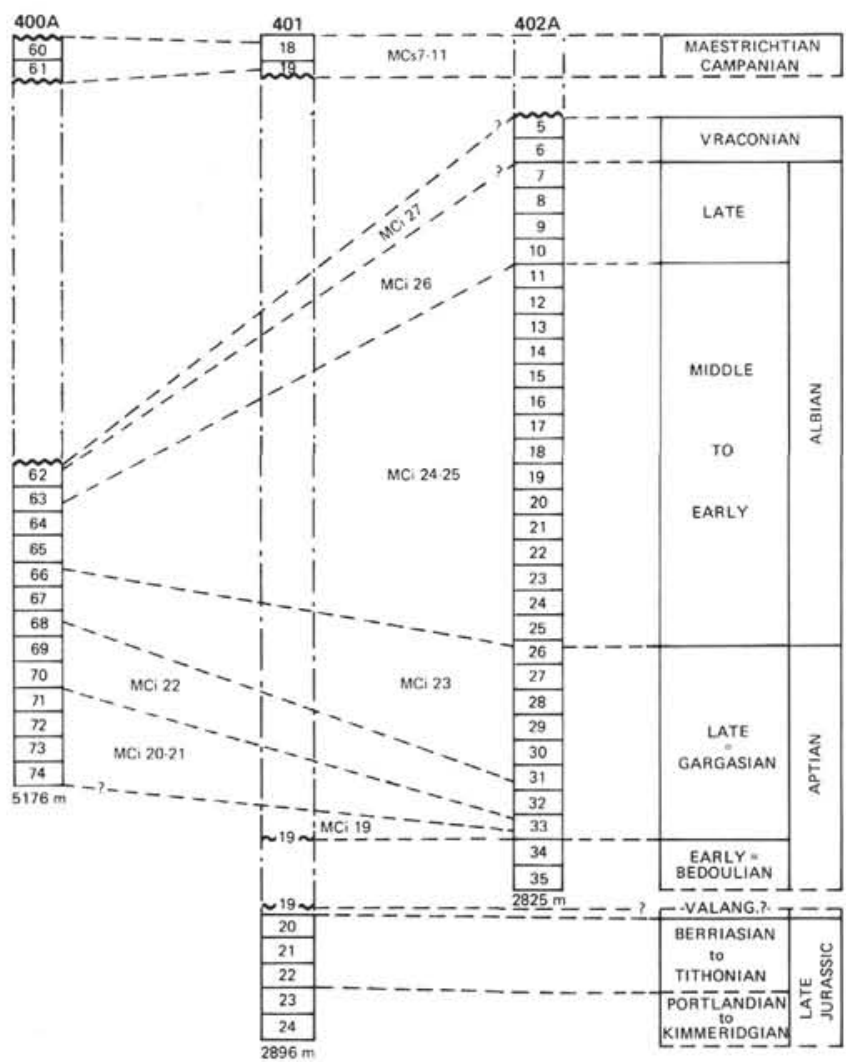

Figure 2. Correlation of the Cretaceous and Upper Jurassic of Hole 400A, Site 401, and Hole 402A. (The three holes were continuously cored; gaps in the logs represent stratigraphic hiatuses. Depths are below mean sea level.)

conditions of deposition, particularly water depth, are difficult to determine (Funnel, 1967). Except for a few species, most of the benthic foraminifers at the two sites are the same. Undoubtedly there are species that preferred deeper water to a shallow environment but, for example, if light intensity were a controlling factor then a shallow turbid environment in which sunlight was reduced because of suspended sediment would provide as acceptable light conditions as a deeper one; the same remarks can be made for other environmental factors such as oxygenation, salinity, etc. "Primitive agglutinates', are a good illustration (see Bock, this volume; Price, 1976).

The Albian foraminifer assemblages at Hole 400A are most similar to those of Sites 305 and 306 (Luterbacher, 1975) where accompanying ostracodes are interpreted being deeper than shelf depths. Conflicting evidence exists in the benthic forms that are present, i.e., Gavelinella spp., Gyroidinoides, Pleurostomella, and Osangularia are common in the shallow water deposits of the Paris Basin (Magniez-Jannin, 1975; Malapris 1965, 1967; Jannin, 1967; Damotte et al., 1973). Determination of water depth on the presence of species that normally would be dissolved in waters deeper than the CCD is not reliable because in turbidite sequences the transported shallow water forms are protected from dissolution by rapid burial (Milliman, 1974; de Graciansky and Chenet, in press; Sigal, in press).
In view of these several differentials, any conclusions on the relative depth of water at the two sites during Albian (particularly) and Aptian time are tenuous. Four useful observations can be made:

1) In Hole $400 \mathrm{~A}$, the high percentage of planktonic foraminifers, mainly in the late Albian sediments, argues for bathyal deposition. It is noteworthy that the earlier Albian strata, comprising alternation of light colored and dark, carbonaceous layers, contain an abundant foraminifer fauna in light layers but not in the dark ones; the latter contain numerous radiolarians, suggestive that dissolution was fostered by the presence of the carbonaceous matter (see Auffret et al., this volume).

2) The presence of sponge spicules, echinoid remains (with very rare Hedbergella washitensis) and particularly of algae limestones ( $L$. amphiroeformis, A. cretacea) and Hensonia lenticularis in the late Albian of Hole 402A points to a shelf environment; except for the "Pithonella facies," which is commonly accepted as an outer shelf deposit (Andri, 1972), planktonic organisms are absent in this sequence.

In the middle and early Albian of this site, planktonic foraminifers are rare to absent and radiolarians few to rare. In contrast, small gastropods and pelecypods are common to abundant.

3) Among the benthic foraminifer assemblages the principal difference between the two sites is the constant presence of Epistominidae in Hole 402A and its total absence in Hole 400A. The Epistominidae family is the only one which has an aragonitic shell, indicating that, during Aptian/Albian times, Hole $402 \mathrm{~A}$ was above the Aragonite-Compensation- Depth and Hole 400A below it. Even if slumping or turbiditic floods existed (see Auffret et al., this volume) in Hole $400 \mathrm{~A}$, the first sedimentation occurred below the A.C.D. because, as noted above, slumped sediments or turbidites protect shells from dissolution. Actually in the Atlantic, undersaturation with respect to aragonite is reached at about 1000 meters (Milliman, 1974). The author therefore concludes that Aptian/Albian sediments of Hole 400A were at least deeper than shelf deposits.

4) The difference of thickness for late Aptian-Albian time in the two sites (400A: about $120 \mathrm{~m}, 402 \mathrm{~A}$; about $280 \mathrm{~m}$ ) and the presence of numerous planktonic forminifers together with "primitive agglutinates" in lower Gargasian layers at Hole 402A, suggests an internal shelf basin connected with open sea where the very restricted layer was deposited probably on the outer shelf or upper slope at Site 401. The infilling of this shelf basin by the important detrital influx during the Albian explains the high sedimentation rate. The lower rate at Hole $400 \mathrm{~A}$ argues for deeper water. A similar interpretation is given for the Aptian/Albian sponge formations of northern Spain (Magniez and Rat, 1972). It is therefore concluded that Site 402 was under shelf conditions and Site 400 under at least bathyal conditions during late Aptian/Albian time.

\section{Upper Cretaceous, Hole 400A and Site 401}

At Site 401 the Upper Cretaceous sediments (Campanian to Maestrichtian) contain foraminifer assemblages of which 
at least 98 to 99 per cent are planktonic; among them, some show signs of dissolution. This indicates a deposit above the CCD but probably not far above it; it probably was a lower bathyal environment.

The disappearance of planktonic foraminifers in Hole $400 \mathrm{~A}$ and the presence of only a few benthic, resistant species point to deposition below the CCD and therefore deeper than Site 401.

\section{ACKNOWLEDGMENTS}

I wish to thank the Deep Sea Drilling Project and IPOD France for inviting me to participate on Leg 48 .

Professor M. Durand Delga (University of Toulouse) determined the Calpionelids; Dr. E. Fourcade (University of Paris) and Dr. M. M. Ramalho (Servicos Geologicos de Portugal) advised me on Upper Jurassic samples. The vast experience of Dr. J. Sigal (Institut Français du Pétrole) concerning Mesozoic microfauna was most profitable to me; I acknowledge each of these scientists for their assistance.

H.M. Bolli, H. Luterbacher, and J. Sigal reviewed this paper; I want to express my sincere thanks.

\section{REFERENCES}

Andri, E., 1972. Mise au point et données nouvelles sur la famille des Calcisphaerulidae Bonet 1956: les genres Bonetocardiella, Pithonella, Calcisphaerula et '“Stomiosphaera," Rev. Micropaléont., v. 15, p. 12-34.

Bouroullec, J. and Deloffre, R., 1976. Relations faciès-environement au Crétacé moyen en Aquitaine occidentale, Bull. Centre Rech.Pau-SNPA, v. 10, p. 535-583.

Caron, M. and Luterbacher, H., 1969. On some type specimens of crétaceous planktonic foraminifers, Contrib. Cushm. Found. Foram. Res., v. 20, p. 23-29.

Chevalier, J., 1960. Contribution à l'étude stratigraphique et micropaléontologique du Crétacé inférieur du Languedoc et de la Provence, Dipl. Etud.Sup., Paris. , 1961. Quelques nouvelles espèces de Foraminifères dans le Crétacé inférieur méditérranéen. Rev. Micropaléont. v. 4 , p. $30-36$

Cuvillier, J., 1961. Stratigraphic correlations by microfacies in western Aquitaine, Internat. Sediment. Petrogr. Series, Leiden (E.J. Brill), v. 2, p. 1-34.

Damotte, R. and Magniez-Jannin, F., 1973. Ostracodes et foraminifères de l'Aptien inférieur du sondage du Bois du Perchoise (Aube), Bull. Inf. Geol. Bass. Paris, p. 3-48.

Dupeuble, P. A., Boillot, G., Lamboy, M. Malod, J., Mauffret, A., and Mougenot, D., 1977. Le passage Jurassique-Crétacé sur la marge continentale atlantique de la Peninsule ibérique, Fifth Réunion Annuelle des Sciences de la Terre, Rennes.

Flandrin, J., Moullade, M., and Porthault, B., 1962. Microfossiles caractéristiques du Crétacé inférieur vocontien, Rev. Micropaléont., v. 4, p. 211-228.

Fourcade, E., 1970. Le Jurassique et le Crétacé aux confins des chaines bétiques et ibériques (Sud-Est de l'Espagne), Thèse Doct. Sciences, Paris.

Funnell, B.M., 1967. Foraminifera and Radiolaria as depth indicators in the marine environment, Marine Geology, v. 5, p. 333-347.

Gonzales-Donoso, J.M., Linares, D., and Oloriz, F., 1974. Sobre la presencia de materiales de edad aptense en el sector de Campillo de Arenas (zona subbetica, provincia de Jaen). Cuad. Geol., p. 89-99. de Graciansky, P. C. and Chenet, P. Y., in press Sedimentological study of Cores 138 to 56 from Hole 398D of Leg 47B; an attempt at reconstruction of paleoenvironments. In Ryan, W. B. F., Sibuet, J. C., et al., Initial Reports of the Deep Sea Drilling Project, v. 47, Part 2: Washington (U.S. Government Printing Office).

Jannin, F., 1967. Les 'Valvulineria"' de l'Albien de l'Aube, Rev. Micropaléont., v. 10, p. 153-178.

Longoria, J.F., 1974. Stratigraphic, Morphologic and Taxonomic studies of aptian planktonic foraminifera, Rev. Espan. Micropal., p. 1-107.

Luterbacher, H., 1972. Foraminifera from the lower Cretaceous and upper Jurassic of the Northwestern Atlantic. In Hollister, C.D., Ewing, J.I., et al., Initial Reports of the Deep Sea Drilling Project, v. 11: Washington (U.S. Government Printing Office), p. 561-593.

1975. Early Cretaceous foraminifera from the Northwestern Pacific: Leg 32 of the Deep Sea Drilling Project. In Larson, R. L., Moberly, R., et al., Initial Reports of the Deep Sea Drilling Project, v. 32: Washington (U. S. Government Printing Office), p. 703-718.

Magniez-Jannin, F., 1975. Les Foraminifères de l'Albien de l'Aube: Paléontologie, stratigraphie, écologie, Cahiers de Paléontologie, C.N.R.S., Paris.

Magniez, F. and Rat, P., 1972. Les Foraminifères des formations à Spongiaires et Tritaxia dans l'Aptien-Albien cantabrique (Espagne), Rev. Esp. Micropal. no. extraordinario. XXX Aniversario E. N. Adaro, p. 159-178.

Malapris, M., 1965. Les Gavelinellidae et formes affines du gisement albien de Courcelles (Aube), Rev. Micropaleont., v. 8 , p. $131-150$.

Malapris-Bizouard, M., 1967. Les Lingulogavelinelles de l'Albien inférieur et moyen de l'Aube, Rev. Micropaléont., v. 10 , p. $128-150$.

Milliman, J. D., 1974. Marine carbonates. Recent sedimentary carbonates, part I: Berlin, Heidelberg, New York (Springer-Verlag).

Moullade, M., 1966. Etude stratigraphique et micropaléntologique du Crétacé inférieur de la "fosse vocontienne". Doc. Labo. Géol. Fac. Sci. Lyon, n. 15. , 1974. Zones de Foraminifères du Crétacé inferieur mesogeen, C.R. Acad. Sci. Paris, Serie D, 278, p. 1813-1816.

Poignant, A., 1965. Révision du Crétacé inférieur en Aquitaine occidentale et méridionale, Thèse Doct. Scineces, Paris.

Price, R.J., 1976. Paleoenvironmental interpretations in the Albian of western and southern Europe, as shown by the distribution of selected Foraminifera, Ist. Int. Symp. on Benthonic Foraminifera, part B, Marine Sediments, Spec. Pu., p. 625-648.

Ramalho, M. M., 1971. Contribution à l'étude micropaléontologique et stratigraphique du Jurassique supérieur et du Crétacé inférieur des environs de Lisbonne (Portugal), Serviços Geologicos de Portugal, Mem. 19 (Nova serie).

Risch, H., 1969. Stratigraphie der Hheren unterkreide der Bayaerischen Kalkalpen mit Hilfe von Mikrofossilien, Ludwig-Maximilians-Universität, München.

Sigal, J., 1976. Essai de zonation du Crétacé méditerranéen à l'aide des Foraminifères planctoniques, Géologie Méditerranéenne, v. 4, p. 99-108.

, in press. Chronostratigraphy and ecostratigraphy of Cretaceous formations, Leg 47B, Site 398D. In Ryan, W. B. F., Sibuet, J. C., et al., Initial Reports of the Deep Sea Drilling Project, v. 47, Part 2: Washington (U.S. Government Printing Office). 

PLATE 1

Figures 1-3 Globotruncana mayaroensis Bolli. Sample 401-18-1, 12-13 cm; × 100.

Figure 4 Racemiguembelina fructicosa (Egger). Sample 401-18-1, 12-13 cm; × 100.

Figures 5-7 Rugoglobigerina scotti (Bronnimann). Sample 401-18-1, 12-13 cm; × 120 .

Figures 8, 9 Globotruncana calcarata Cushman. Sample 401-18-2, 62-63 cm; × 100.

Figures 10, 11 Planomalina buxtorfi (Gandolfi). Sample 400A-62-1, 70-73 cm; $\times 75$.

Figures 12, 13 Rotalipora ticinencis (Gandolfi). Sample 400A-62-2, 28-30 cm; × 75 .

Figures 14, 15 Ticinella breggiensis (Gandolfi). Sample 400A-62-2, 28-30 cm; × 120 . 
PLATE 1
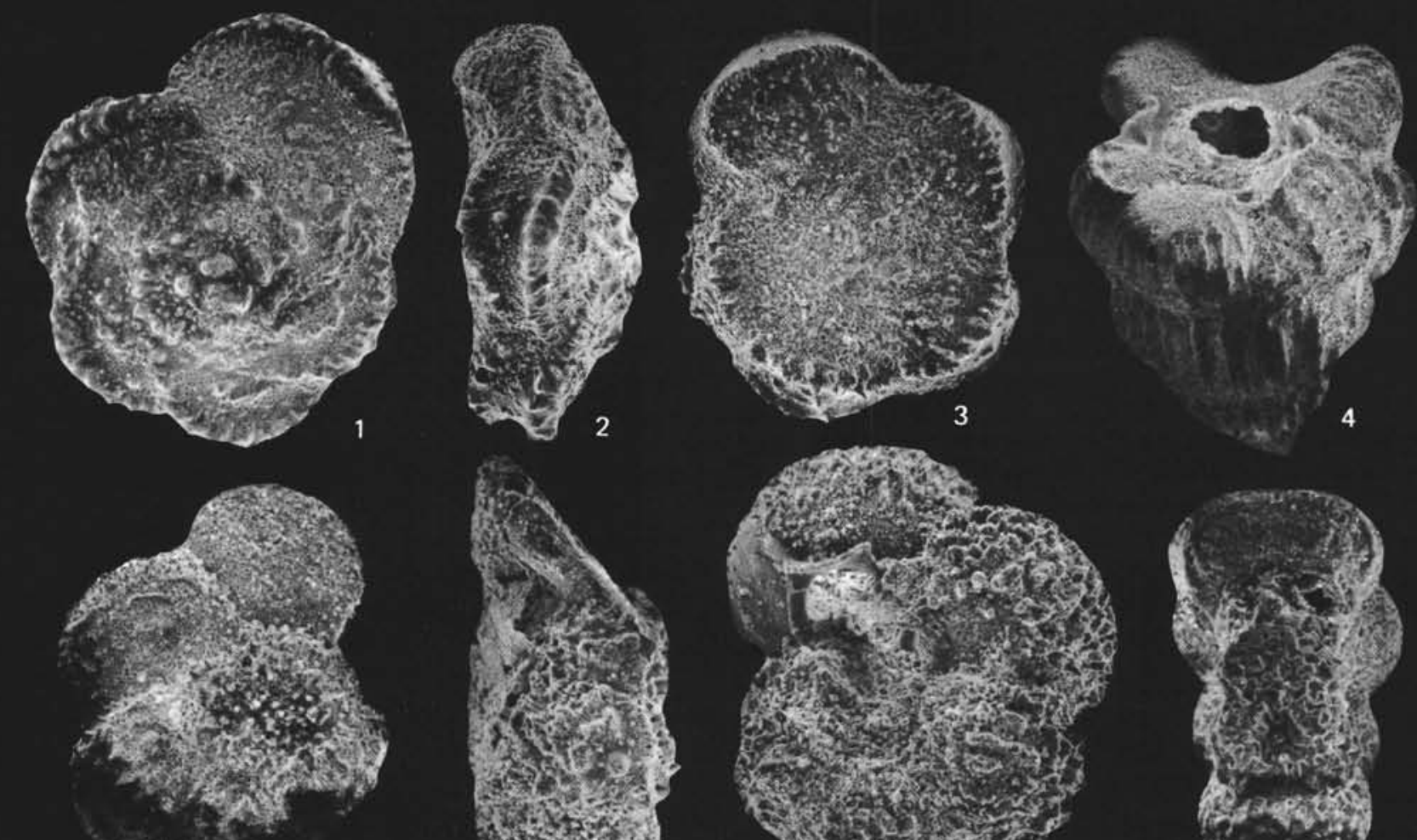

5
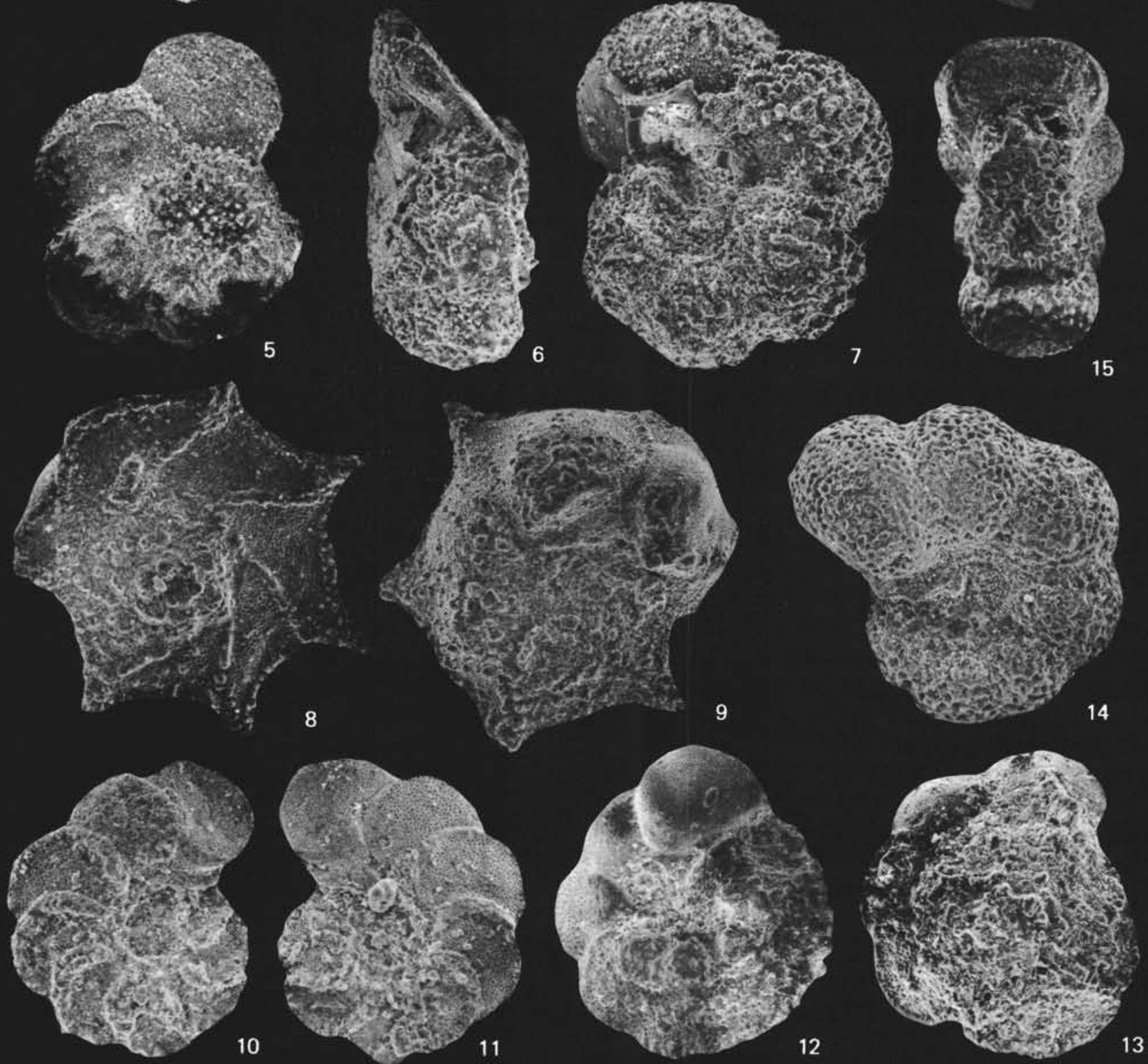


\section{PLATE 2}

Figures 1-3 Hedbergella (Ticinella) bejaouaensis Sigal. Sample 400A-68-1, 72-73 cm; $\times 120$.

Figures 4-6 Hedbergella trocoidea (Gandolfi). Sample 400A-71-2, 37-39 cm; × 120 .

Figures 7-9 Globigerinelloides algerianus Cushman and Ten Dam.

Sample 400A-71, CC; $\times 120$.

Figures 10, 11 Planomalina cheniourensis (Sigal). Sample 402A-33-2, 56-57 cm; × 120 .

Figures 12-14 Osangularia utaturensis (Sastry and Sastri). 12, 13. Sample 400A-65-2, 42-46 cm; $\times 100$. 14. Sample 400A-64-4, 59-62 cm; $\times 100$.

Figure 15 Tritaxia pyramidata Reuss.

Sample 400A-64-4, 59-62 cm; $\times 75$.

Figure 16 Pseudoclavulina gaultina (Morozova). Left: Sample 400A-64-4, 59-62 cm; $\times 60$.

Right: Sample 400A-62-1, 70-73 cm; $\times 60$. 

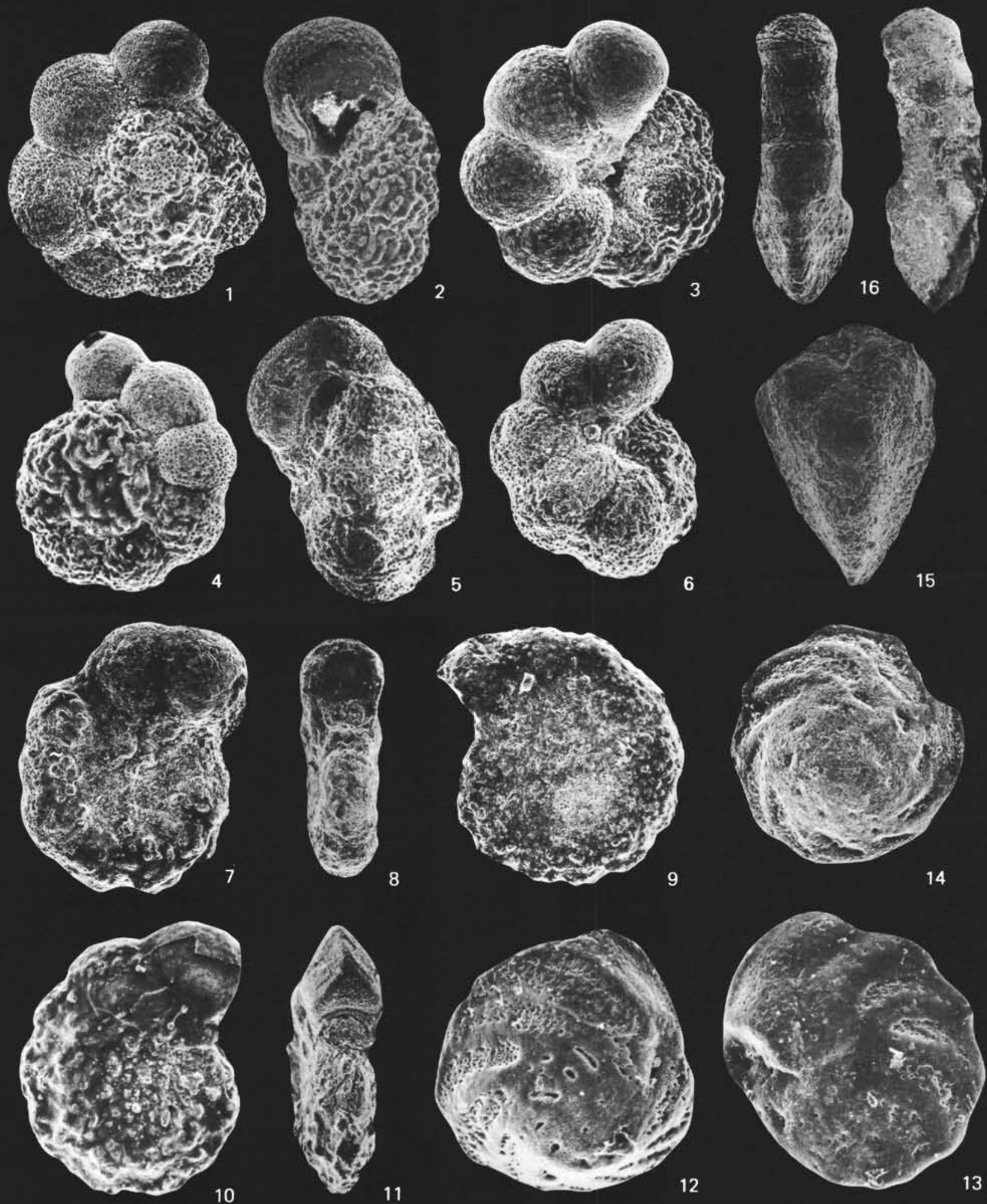


\section{PLATE 3}

Figures 1, 2 Gyroidinoides primitiva (Hofker).

Sample 400A-66-2, 63-67 cm; × 100.

Figures 3, $4 \quad$ Pleurostomella subnodosa Reuss.

Sample 400A-64-2, 67-72 cm; $\times 100$.

Figure $5 \quad$ Saracenaria spinosa Eichenberg.

Sample 402A-33-1, 111-114 cm; $\times 60$.

Figure $6 \quad$ Lenticulina rotulata Lamarck.

Sample 400A-62-2, 28-30 cm; $\times 60$.

Figures 7, 8 Schackoina cabri Sigal.

Sample 402A-33-4, 27-29 cm:

7. $\times 200$.

8. $\times 120$.

Figures 9, 10 Schackoina pustulans Bolli.

Sample 402A-33-4, 27-29 cm; × 200.

Figures 11-14 Schackoina cabri Sigal.

Sample 401-19-1, 123-125 cm; $\times 200$.

Figures 15, 16 Globigerinelloides duboisi (Chevalier).

Sample 401-19-1, 123-125 cm; $\times 250$.

Figures 17, 18 Globigerinelloides gottisi (Chevalier).

Sample 401-19-1, 123-125 cm; $\times 200$. 


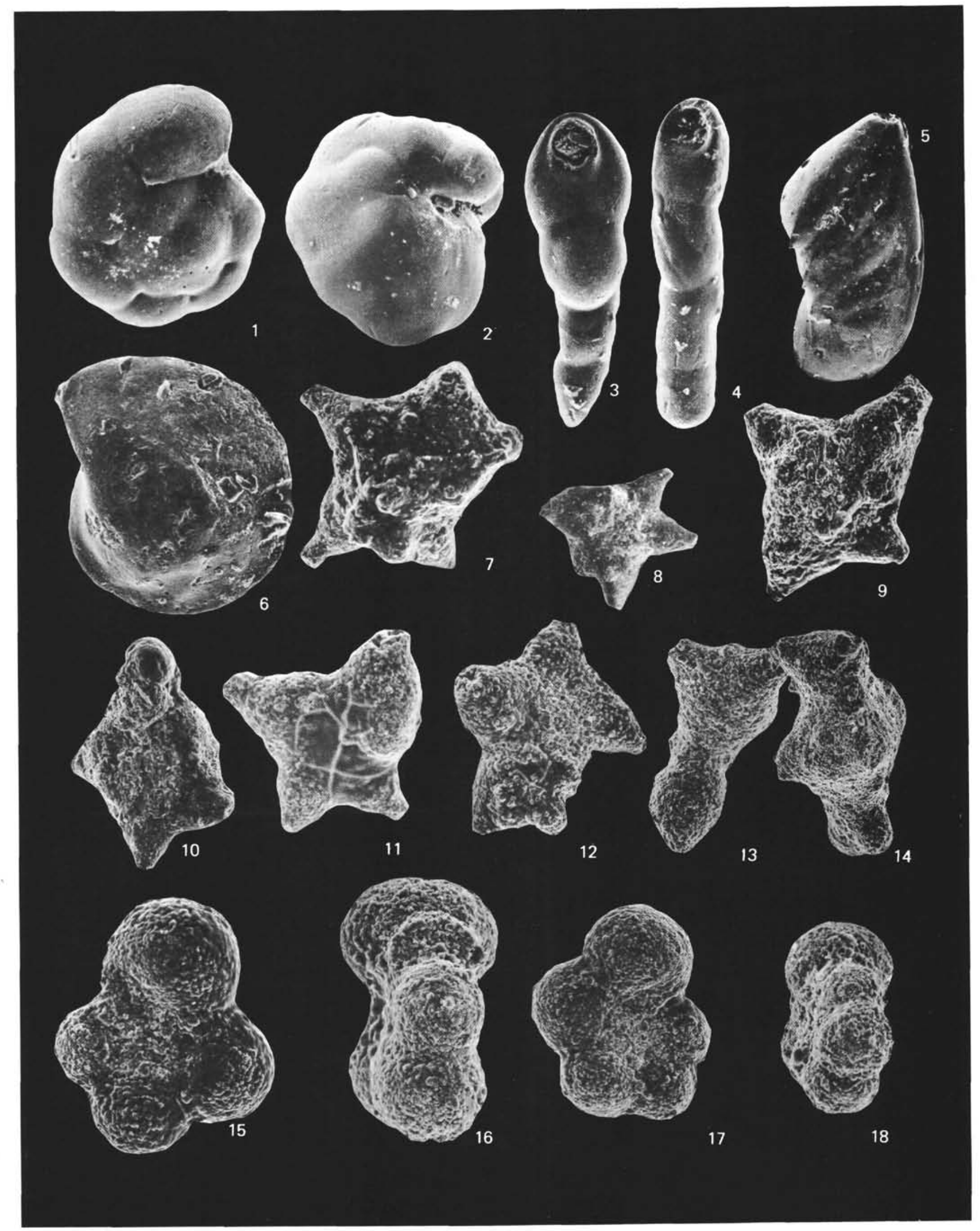


PLATE 4

Figure $1 \quad$ Globorotalites aptiensis Bettenstaedt. Sample 402A-34-2, 34-38 cm; $\times 75$.

Figure 2 Gavelinella cf. brotzeni (Gandolfi).

Sample 402A-33-3, 109-113 cm; × 100.

Figure 3 Gavelinella barremiana Bettenstaedt. Sample 402A-34-2, 34-38 cm; × 120 .

Figures 4, 7 Trochamminoides sp.

Sample 402A-33-1, 111-114 cm; $\times 100$.

Figures 5, 6 Glomospira gordialis (Jones and Parker). Sample 400A-72-3, 86-89 cm; $\times 120$.

Figure $8 \quad$ Ammodiscus sp.

Sample 402A-33-1, 111-114 cm; × 120 .

Figure 9 Lenticulina ouachensis (Sigal).

Sample 402A-34-4, 25-29 cm; $\times 75$.

Figures 10-12 Lingulogavelinella gr. intermedia (Berthelin). Sample 402A-33-1, 111-114 cm; × 150 . 

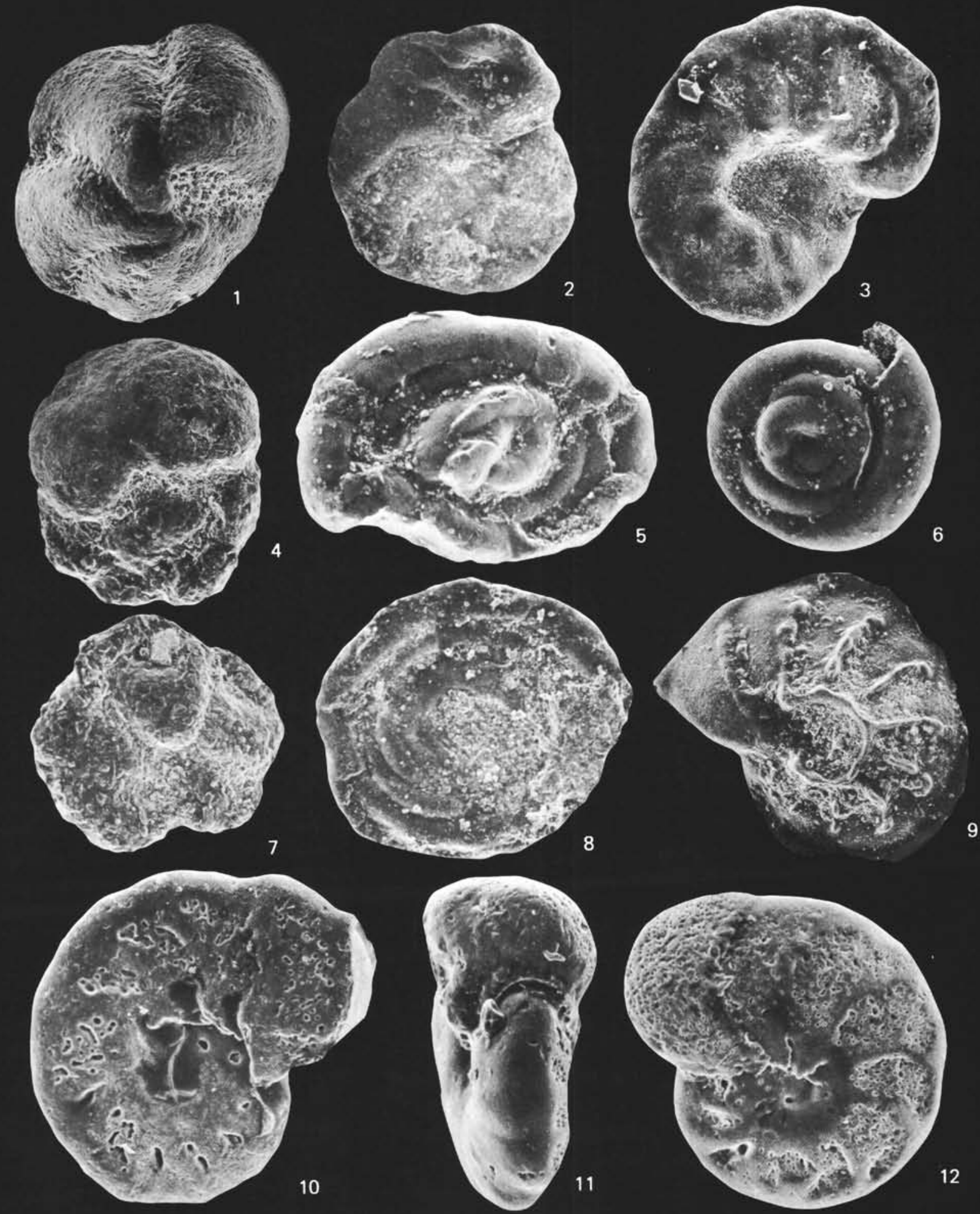


\section{PLATE 5}

Figure 1 Conicospirillina basiliensis Mohler. Sample 401-23-2, 32-33 cm; $\times 50$.

Figure 2 Nautiloculina oolithica Mohler.

Sample 401-24-1, 24-26 cm; $\times 40$.

Figure 3 Kurnubia ? (oblique transverse section).

Sample 401-23-2, 32-33 cm; $\times 50$.

Figure 4 Bacinella irregularis Radoicic and Lithocodium aggregatum Elliot with some echinid remains.

Sample 401-24-1, 10-14 cm; $\times 10$.

Figure 5 Pelletoid biocalcarenite: this facies is very frequent in the Kimmeridgian and Portlandian of the mesogean regions.

Sample 401-23-2, 7-10 cm; $\times 20$. 
PLATE 5
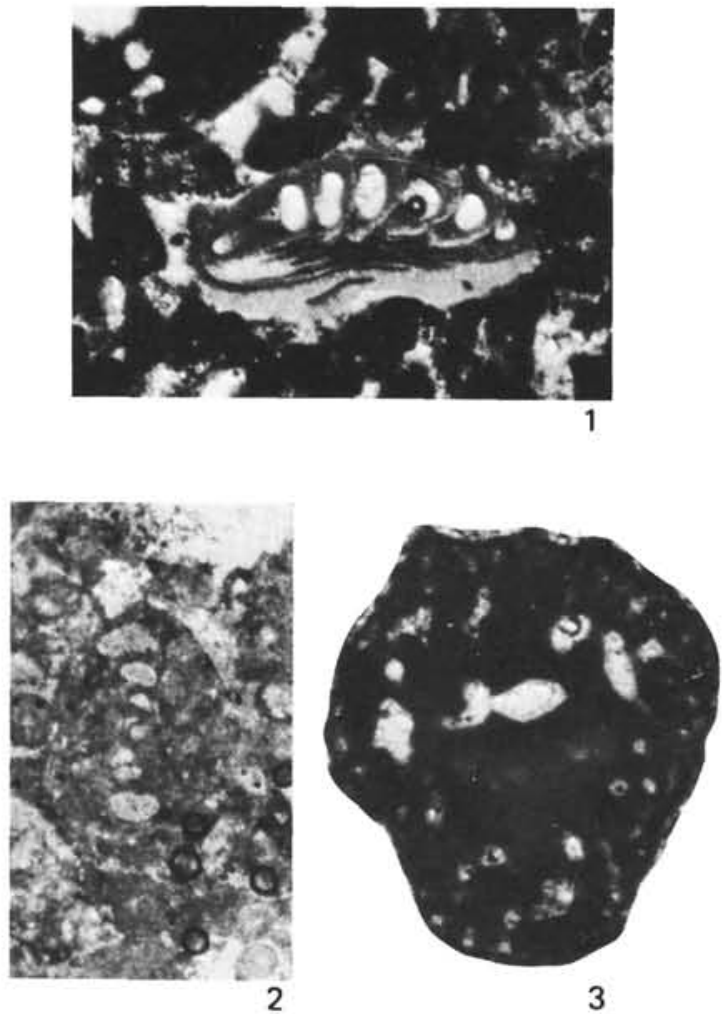

3

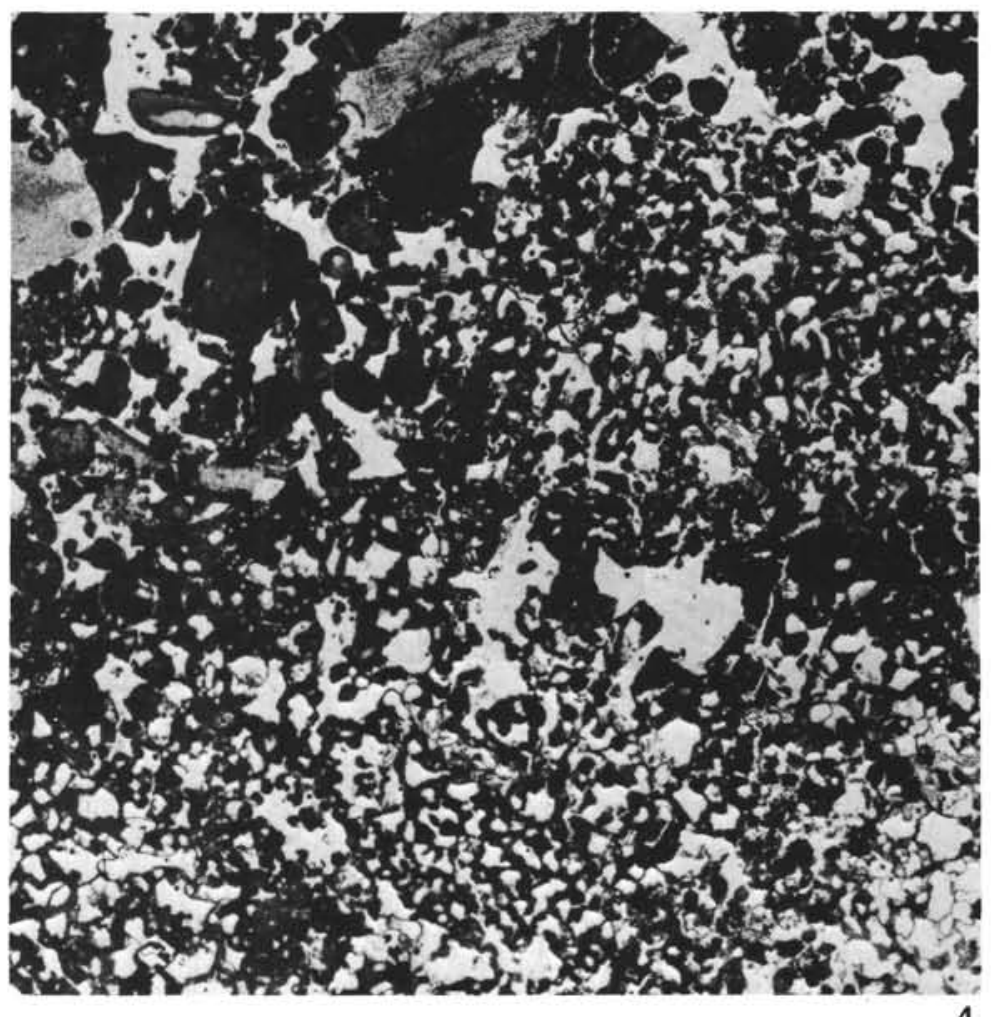

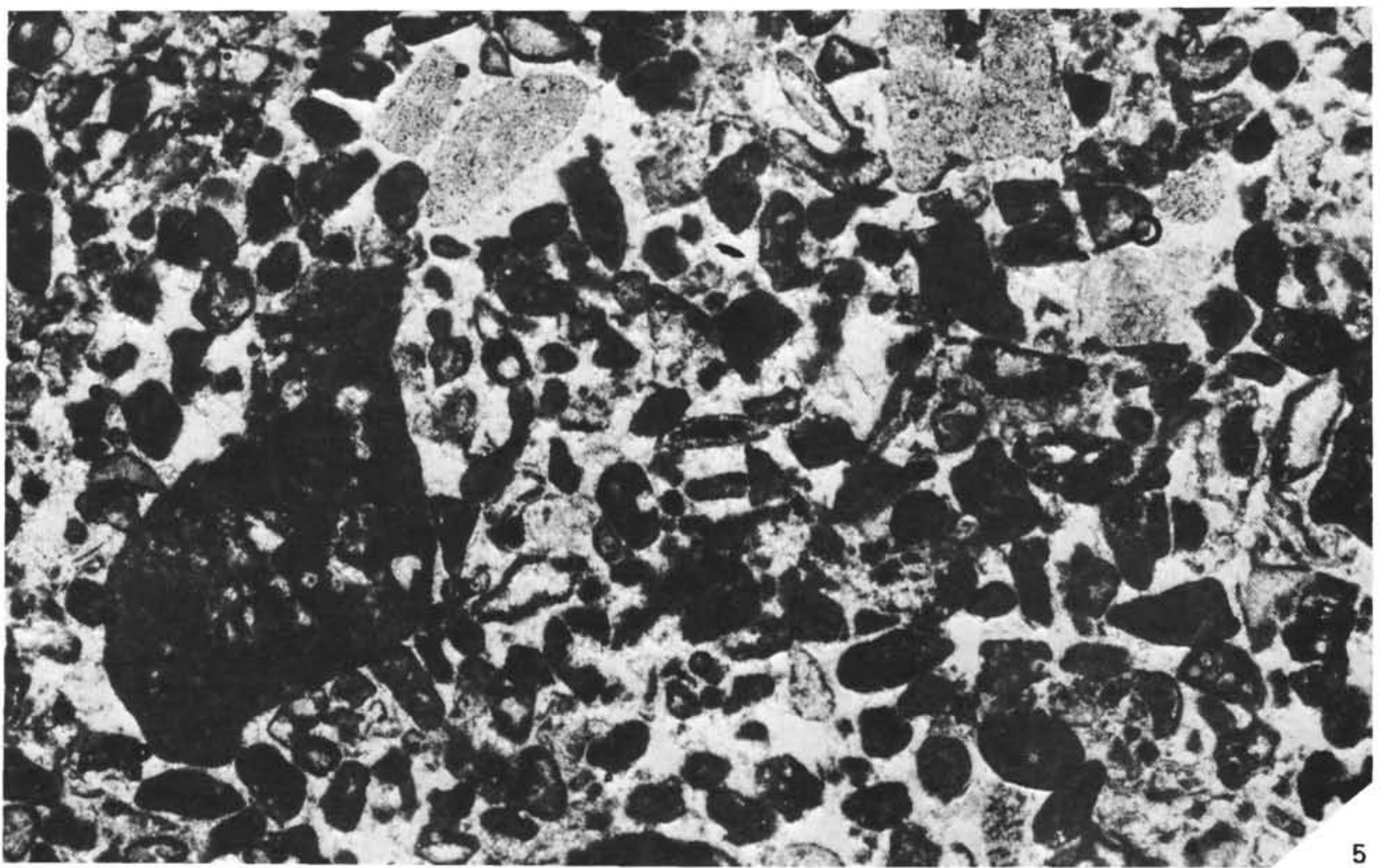




\section{PLATE 6}

Figure 1 Bioclastic limestone with frequent algae (Agardhiellopsis cretacea Lemoine and Lithophyllum amphiroeformis Rothpletz), bryozoa and echinid remains. Epicontinental facies frequent in the Albian of North Pyrenean border.

Figure 2 Same that the previous one with Hensonia lenticularis (Henson). Sample 402A-8-1, 3-5 cm; $\times 30$.

Figure 3 Micritic limestone with numerous Pithonella ovalis (Kaufmann), some Calcisphaerula innominata Bonet and rare sponge spicules. Frequent facies of the Albian (mainly upper Albian) to the Turonian.

Sample 402A-6-1, 16-20 cm; $\times 40$. 


\section{PLATE 6}
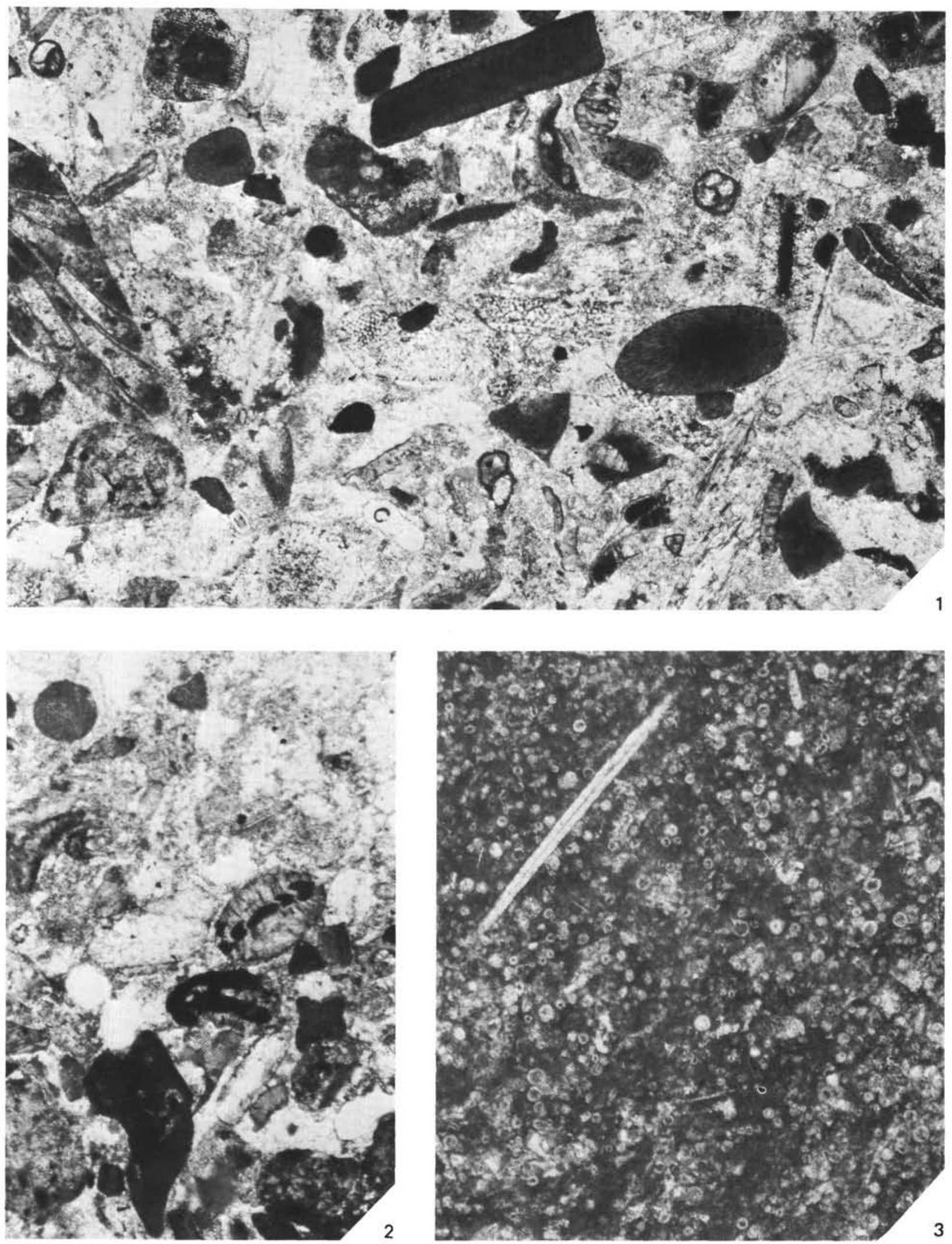
PLATE 7

Figure 1 Micritic limestone crammed with large sponge spicules. Classic facies of the Albian in Aquitania. Sample 402A-5-1, 140-143 cm; $\times 40$.

Figure 2 Micritic limestone with abundant echinid remains. In association, some very rare sections of Hedbergella washitensis (Carsey). Probably Uppermost Albian (Vraconian). Sample 402A-5-1, 12-15 cm; $\times 30$. 
PLATE 7
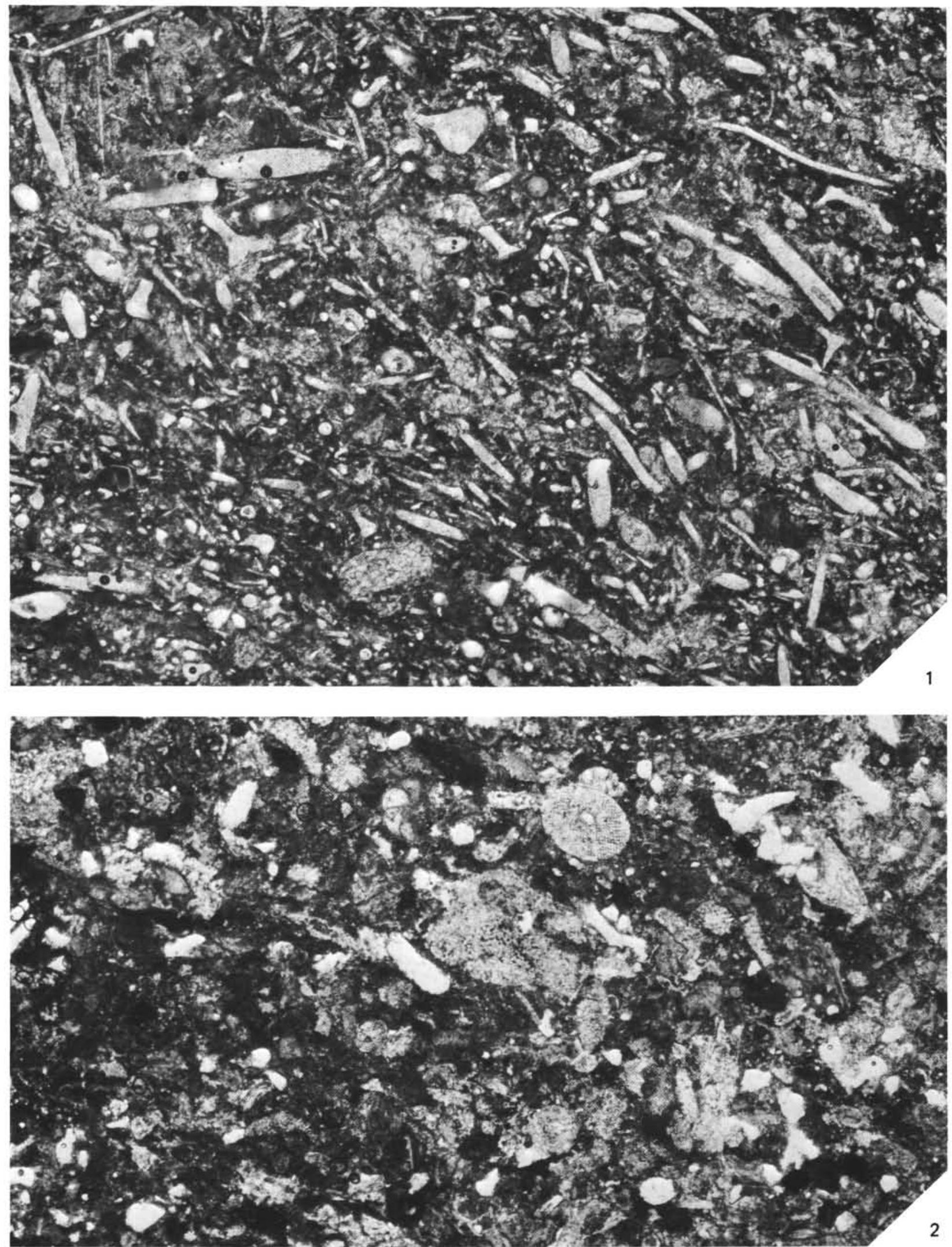